\title{
PRODUKTIVITAS TANAMAN UBI JALAR LOKAL (Ipomoea batatas) DENGAN PEMUPUKAN SERASAH KOMPOS KAMBING DI LAHAN BEKAS PENAMBANGAN BATU KAPUR
}

\author{
Doso Sarwanto dan Sari Eko Tuswati \\ Fakultas Peternakan Universitas Wijayakusuma Purwokerto Jawa Tengah 53135 \\ sariekot.amin@gmail.com
}

\begin{abstract}
ABSTRAK
Penelitian bertujuan mengevaluasi pengaruh untuk merevegetasi lahan terbuka bekas penambangan batu kapur dengan tanaman ubi jalar lokal (Ipomoea batatas) yang dipupuk dengan serasah kompos kambing milik peternak. Metode penelitian yang digunakan adalah metode eksperimental di lahan terbuka bekas penambangan batu kapur dengan mengggunakan pola percobaan Faktorial dengan rancangan acak lengkap (RAL) yang masing-masing perlakuan diulang sebanyak 3 kali. Faktor I adalah tiga jenis ubi jalar lokal yaitu ubi jalar warna ungu (U), warna putih $(P)$ dan warna kuning $(K)$, sedangkan Faktor II adalah level pemupukan serasah kompos kambing yaitu $\mathrm{kl}$ : Level pemupukan serasah kompos kambing $0,5 \mathrm{~kg} / \mathrm{m}^{2}, k 2$ : Level pemupukan serasah kompos kambing $1 \mathrm{~kg} / \mathrm{m}^{2}$, $\mathrm{k} 3$ : Level pemupukan serasah kompos kambing 1,5 $\mathrm{kg} / \mathrm{m}^{2}$ dan $\mathrm{k4}$ : Level pemupukan serasah kompos kambing $2 \mathrm{~kg} / \mathrm{m}^{2}$. Hasil penelitian menunjukkan bahwa jenis ubi jalar lokal dan level pemupukan seresah kompos kambing berpengaruh nyata $(P<$ $0,05)$ terhadap produktivitas ubi jalar lokal, namun tidak terjadi interaksi $(P>0,05)$ antara jenis ubi jalar dengan level pemupukan serasah kompos kambing kecuali terhadap diameter ubi jalar $(P$ $<$ 0,01). Kesimpulan yang diperoleh dari hasil penelitian ini adalah semua jenis ubi jalar lokal dapat tumbuh berkembang di lahan terbuka bekas penambangan batu kapur dengan level pemupukan serasah kompos kambing minimal 10 ton/ha.
\end{abstract}

Kata Kunci : Pegunungan kapur, Ubi jalar lokal, serasah kompos kambing

\section{PENDAHULUAN}

Sejalan dengan kebijakan pemerintah dalam membangun infrastruktur di berbagai pelosok wilayah Indonesia telah berdampak pada meningkatnya kegiatan penambangan batu kapur di pegunungan kapur. Menurut Sarwanto et al. (2015) salah satu dampak negatif dari penambangan batu kapur adalah terbentuknya lahan terbuka bekas penambangan batu kapur yang tidak didayagunakan. Lahan terbuka bekas penambangan batu kapur akan semakin luas dari waktu ke waktu yang berakibat terhadap perubahan ekosistem pegunungan kapur.
Perubahan ekosistem akan menyebabkan menurunnya produktivitas tanaman pangan yang sangat dikembangkan oleh masyarakat. Selanjutnya Sarwanto dan Tuswati (2018) menyatakan bahwa tanaman pangan juga menghasilkan limbah berupa jerami daun yang merupakan sumber hijauan pakan ternak kambing, sehingga perubahan ekosistem akan menurunkan pula tingkat produktivitas ternak kambing di wilayah pegunungan kapur. Padahal menurut Sarwanto dan Tuswati (2016) masyarakat pegunungan kapur banyak yang memelihara ternak kambing sebagai penopang ekonomi keluarga, oleh karena itu penurunan 
produktivitas ternak kambing akan berakibat pula pada menurunnya tingkat kesejahteraan peternak.

Salah satu upaya untuk mengatasi permasalahan tersebut adalah dilakukannya revegetasi melalui introduksi tanaman pangan di lahan terbuka bekas penambangan batu kapur. Kendala utama merevegetasi lahan terbuka bekas penambangan batu adalah kandungan unsur hara tanah kapur yang rendah. Penelitian Sarwanto dan Prayitno (2015) menunjukkan bahwa lahan terbuka bekas penambangan batu kapur mempunyai kandungan unsur hara tanah yang rendah. Kandungan unsur hara tanah pada lahan bekas penambangan batu kapur mengandung Nitrogen total hanya berkisar 0,049-0.141\%, kandungan $\mathrm{P}_{2} \mathrm{O}_{5}$ total $0,067-0,133 \%$; dan kandungan $\mathrm{K}_{2} \mathrm{O}$ total $0,086-0,100 \%$.

Kesuburan tanah di lahan terbuka bekas penambangan batu kapur dapat ditingkatkan dengan pemberian pupuk organik berupa seresah kompos kambing yang terbuat dari tumpukan feses, urin, dan sisa pakan. Menurut Azizah et al. (2017) kompos kambing mempunyai fungsi yang penting bagi tanaman karena dapat menggemburkan lapisan permukaan tanah, meningkatkan populasi jasad renik, mempertinggi daya serap, dan daya simpan air sehingga dapat meningkatkan kesuburan tanah. Hasil penelitian Sarwanto dan Tuswati (2017) serta Sarwanto dan Tuswati (2018) menunjukkan bahwa lahan terbuka bekas penambangan batu kapur dapat dimanfaatkan untuk menanam rumput gajah kerdil (Pennisetum purpureum 'Mott') dengan penambahan serasah kompos kambing sebanyak 1,5 kg/m². Berdasarkan hasil penelitian tersebut maka lahan terbuka bekas penambangan batu kapur dimungkinkan untuk dapat didayagunakan untuk budidaya tanaman pangan. Di mana, sistem pemeliharaan ternak kambing di wilayah pegunungan kapur adalah kandang lemprakan yang berpotensi menghasilkan serasah kompos kambing dalam jumlah banyak.

Budidaya tanaman pangan yang tepat untuk dibudidayakan di lahan bekas penambangan batu kapur adalah ubi jalar lokal yang digemari oleh masyarakat pegunungan kapur. Menurut Ginting et al. (2017) salah satu tanaman pangan yang sangat dikenal dan disukai oleh masyarakat Indonesia adalah ubi jalar (Ipomoea batatas) yang bernilai ekonomi dan mengandung nutrisi tinggi serta dapat tumbuh pada berbagai kondisi tanah, sehingga sangat strategis untuk dikembangkan di daerah marjinal. Selain itu tanaman ubi jalar juga menghasilkan limbah jerami daun yang dapat digunakan sebagai hijauan pakan ternak kambing. Oleh karena itu perlu dilakukan kajian mengenai budidaya beberapa ubi jalar lokal di lahan bekas penambangan batu kapur dengan berbagai tingkat pemupukan serasah kompos kambing. Keberhasilan penelitian ini diharapkan dapat mengurangi kerusakan ekosistem akibat penambangan batu kapur dan meningkatkan ketersediaan pangan dan hijauan pakan ternak kambing. 


\section{BAHAN dan METODE}

Materi penelitian yang digunakan adalah tiga varietas ubi jalar (Ipomoea batatas) lokal yaitu ubi jalar warna putih, warna kuning, dan warna ungu. Seresah kompos kambing yang digunakan sebagai sumber pupuk. Penelitian dilakukan di lahan terbuka bekas penambangan batu kapur, pegunungan kapur Gombong yang terletak di Desa Kalisari Kecamatan Rowokele Kabupaten Kebumen Jawa Tengah dan Laboratorium Tanah Fakultas Pertanian Unsoed, Purwokerto untuk pengujian tanah dan nutris tanaman.

Satuan percobaan dalam penelitian ini disusun dalam rancangan acak lengkap (RAL) faktorial Ada dua faktor yang diujikan dalam percobaan ini, yaitu varietas ubi jalar lokal dan level pemupukan serasah kompos kambing. Masing-masing perlakuan diulang sebanyak 3 kali, adapun perlakuan penelitian adalah sebagai berikut :

Faktor I ( jenis ubi jalar lokal )

$\mathrm{U}$ : Ubi jalar warna ungu

$P$ : Ubi jalar warna putih

$\mathrm{K}$ : Ubi jalar warna kuning

Faktor II ( level pemupukan serasah kompos kambing )

k1: Level pemupukan serasah kompos kambing $0,5 \mathrm{~kg} / \mathrm{m}^{2}$

k2: Level pemupukan serasah kompos kambing $1 \mathrm{~kg} / \mathrm{m}^{2}$

k3: Level pemupukan serasah kompos kambing $1,5 \mathrm{~kg} / \mathrm{m}^{2}$

k4: Level pemupukan serasah kompos kambing $2 \mathrm{~kg} / \mathrm{m}^{2}$
Waktu pemanenan ubi jalar pada penelitian ini adalah pada saat ubi jalar berumur 3,5 bulan. Peubah respon yang diukur meliputi: produksi total ubi jalar (ton/ha), produksi ubi jalar per tanaman (gram), berat sampel ubi jalar (gram), panjang sampel ubi jalar $(\mathrm{cm})$, dan diameter sampel ubi jalar $(\mathrm{cm})$. Data yang diperoleh selanjutnya dianalisis dengan analisis variansi dan apabila terdapat perbedaan dilanjutkan dengan uji lanjut menggunakan uji beda nyata terkecil (BNT) sesuai petunjuk Steel dan Torrie (1993).

\section{HASIL DAN PEMBAHASAN}

Tanah merupakan media tumbuh tanaman yang berasal dari hasil pelapukan batuan. Pembentukan tanah sangat dipengaruhi oleh faktor-faktor lingkungan, seperti bahan induk, iklim, topografi, vegetasi atau organisme, dan waktu pelapukan. Dalam proses pembentukan tanah, faktor-faktor tersebut di atas bekerja secara dinamis dan simultan melalui proses fisika, kimia, biologis, maupun proses ketigatiganya bekerja secara bersamaan serta saling berinteraksi. Proses pembentukan tanah berjalan terus menerus dan saling mempengaruhi, dominasi dari masing-masing faktor pembentuk tanah sangat beragam (Balitbangtan, 2015)

Kondisi tanah di lahan bekas penambangan batu kapur lebih ditentukan oleh lamanya waktu setelah penambangan. Lahan terbuka bekas penambangan batu kapur yang telah berumur lebih dari 20 tahun (> 20 tahun) mempunyai kondisi tanah yang lebih baik dibandingkan dengan lahan terbuka bekas 
penambangan batu kapur yang berumur di bawah 20 tahun $(<20$ tahun). Hasil analisis kimia komposisi tanah dari lahan bekas penambangan batu kapur secara lengkap dapat dilihat pada Tabel 1 berikut ini. Berdasarkan hasil analisis kimia tanah seperti pada Tabel 1 memperlihatkan bahwa lahan terbuka bekas penambangan batu kapur yang telah berumur lebih dari 20 tahun (>20 tahun) mempunyai tingkat kesuburan rendah - sedang, adapun lahan terbuka bekas penambangan batu kapur yang berumur di bawah 20 tahun $(<20$ tahun $)$ mempunyai tingkat kesuburan sangat rendah rendah.

Tabel 1. Komposisi Tanah Lahan Terbuka Bekas Penambangan Batu Kapur di Lokasi Peneltian.

\begin{tabular}{|c|c|c|}
\hline Parameter & Lahan $<20$ Tahun & Lahan > 20 Tahun \\
\hline Karbon Organik (\%) & 0,150 & 0,652 \\
\hline Bahan Organik (\%) & 0,259 & 1,124 \\
\hline $\mathrm{pH} \mathrm{H} \mathrm{H}_{2} \mathrm{O}$ & 7,44 & 7,45 \\
\hline Nitogen Total (\%) & 0,196 & 0,251 \\
\hline $\mathrm{P}_{2} \mathrm{O}_{5}$ Total $(\%)$ & 0,089 & 0,140 \\
\hline $\mathrm{K}_{2} \mathrm{O}$ Total $(\%)$ & 0,240 & 0,293 \\
\hline C / N Ratio & 0,77 & 2,60 \\
\hline Pasir (\%) & 77,973 & 46,923 \\
\hline Debu $(\%)$ & 10,670 & 35,867 \\
\hline Liat (\%) & 11,357 & 17,210 \\
\hline
\end{tabular}

Tabel 2. Komposisi Serasah Kompos Kandang yang Digunakan dalam Peneltian ini.

\begin{tabular}{lrr}
\hline \multicolumn{1}{c}{ Parameter } & Serasah kompos kambing $^{1}$ & Pembanding $^{2}$ \\
\hline Karbon Organik (\%) & 22,278 & - \\
Bahan Organik (\%) & 38,410 & - \\
pH $\mathrm{H}_{2} \mathrm{O}$ & 8,64 & 7,08 \\
Nitogen Total (\%) & 5,498 & 1,144 \\
$\mathrm{P}_{2} \mathrm{O}_{5}$ Total (\%) & 1,112 & 0,264 \\
$\mathrm{~K}_{2} \mathrm{O}$ Total (\%) & 0,582 & 0,423 \\
\hline C / N Ratio & $\mathbf{4 , 0 6}$ & $\mathbf{1 9 , 9 1}$ \\
\hline
\end{tabular}

Keterangan: ${ }^{1}$ ) serasah kompos kambing milik kelompok tani ternak di lokasi penelitian. ${ }^{2}$ ) Azizah et al. (2017).

Tabel 3. Hasil penelitian pengaruh jenis ubi jalar lokal dan serasah kompos kambing terhadap produktivitas ubi jalar di lahan bekas penambangan batu kapur

\begin{tabular}{|c|c|c|c|c|c|}
\hline Perlakuan & $\begin{array}{l}\text { Produksi Ubi } \\
\text { Jalar (ton/ha) }\end{array}$ & $\begin{array}{l}\text { Produksi Ubi per } \\
\text { tanaman (gram) }\end{array}$ & $\begin{array}{l}\text { Bobot Ubi } \\
\text { (gram) }\end{array}$ & $\begin{array}{l}\text { Panjang Ubi } \\
(\mathrm{cm})\end{array}$ & $\begin{array}{l}\text { Diameter Ubi } \\
(\mathrm{cm})\end{array}$ \\
\hline Uk1 & $9,3^{\text {aa }}$ & $116,7^{\text {ad }}$ & $83,3^{\text {ac }}$ & $12,0^{\text {ab }}$ & $3,1^{\text {ac }}$ \\
\hline $\mathrm{Uk} 2$ & $10,8^{\mathbf{a b}}$ & $153,3^{\text {ae }}$ & $100,0^{\text {ac }}$ & $13,8^{\text {ac }}$ & $3,6^{\text {ac }}$ \\
\hline Uk3 & $11,6^{\mathrm{ab}}$ & $191,7^{\text {af }}$ & $155,0^{\text {ad }}$ & $15,4^{\text {ac }}$ & $4,8^{\text {ad }}$ \\
\hline Uk4 & $10,5^{\mathrm{ab}}$ & $136,7^{\text {ae }}$ & $105,0^{\text {ac }}$ & $14,3^{\text {ac }}$ & $3,9^{\text {ad }}$ \\
\hline Pk1 & $15,7^{\text {aa }}$ & $126,7^{\text {bd }}$ & $100,0^{\text {ac }}$ & $8,7^{\text {ab }}$ & 3,5 bc \\
\hline $\mathrm{Pk} 2$ & $18,1^{\text {ab }}$ & $168,3^{\text {be }}$ & $90,0^{\text {ac }}$ & $11,5^{\text {ac }}$ & 3,9 bc \\
\hline $\mathrm{Pk} 3$ & $21,5^{\mathrm{ab}}$ & $276,7^{\text {bf }}$ & $153,3^{\text {ad }}$ & $16,3^{\text {ac }}$ & $4,8^{\text {bd }}$ \\
\hline $\mathrm{Pk} 4$ & $20,5^{\mathrm{ab}}$ & 205,0 be & $128,3^{\text {ac }}$ & $24,0^{\text {ac }}$ & $4,9^{\text {bd }}$ \\
\hline $\mathrm{Kk} 1$ & $15,1^{\text {ba }}$ & $135,0^{\mathrm{cd}}$ & $118,3^{\text {bc }}$ & $12,0^{\text {ab }}$ & $3,7^{\text {bc }}$ \\
\hline $\mathrm{Kk} 2$ & $19,7^{\mathbf{b b}}$ & $231,7^{\text {ce }}$ & $140,0^{\text {bc }}$ & $14,5^{\text {ac }}$ & $4,2^{b c}$ \\
\hline $\mathrm{Kk} 3$ & $21,8^{\mathbf{b b}}$ & $236,7^{\text {cf }}$ & $203,3^{\text {bd }}$ & $13,9^{\text {ac }}$ & $5,4^{\text {bd }}$ \\
\hline Kk4 & $21,1^{\mathbf{b b}}$ & $220,0^{\text {ce }}$ & $190,0^{\text {bc }}$ & $14,1^{\text {ac }}$ & $4,7^{\text {bd }}$ \\
\hline
\end{tabular}


Lahan terbuka bekas penambangan batu kapur yang digunakan dalam penelitian adalah lahan yang telah berumur lebih dari 20 tahun, sehingga masih tetap diperlukan penambahan serasah kompos kambing untuk meningkatkan kesuburan tanah.

Adapun kompos yang digunakan adalah serasah kompos kambing yang telah berumur \pm 1 tahun milik kelompok ternak. Hasil analisis kimia serasah kompos kambing pada penelitian ini lebih rendah dibandingkan dengan penelitian sebelumnya (Tabel 2).

Hasil penelitian secara umum menunjukkan bahwa jenis ubi jalar lokal dan level pemupukan memberikan pengaruh terhadap produktivitas ubi jalar yang meliputi produksi total (ton/ha), produksi ubi pertanaman (gram), panjang ubi (cm), bobot ubi (gram), dan diameter ubi $(\mathrm{cm})$ seperti pada Tabel 3.

\section{Produksi Total Ubi Jalar (ton/ha)}

Di Indonesia produksi ubi jalar lokal di tingkat lapangan hanya sebesar 10 ton/ha, sedangan di tingkat penelitian dapat mencapai 20 - 30 ton/ha (Limbongan dan Soplanit 2007). Hasil penelitian menunjukkan bahwa produksi total ubi jalar setiap hektarnya diperoleh berkisar 9,3 - 21,8 ton/ha, produksi ini tidak jauh berbeda dengan hasil penelitian Susanto et al. (2014) di wilayah Kabupaten Malang yang hanya menghasilkan ubi jalar sebanyak 15,2 ton/ha meskipun telah dipupuk dengan kompos sapi sebesar 20 ton/ha. Meskipun demikian produksi ubi jalar tersebut masih rendah dibandingkan produktivitas ubi jalar hasil penelitian Ginting et al. (2017) yang dilakukan di Kabupaten Deli Serdang dengan penambahan pupuk organik bokashi jerami padi sebanyak 5 ton/ha yang menghasilkan ubi jalar sebesar $24-25$ ton/ha. Hasil tersebut juga tidak jauh berbeda dengan hasil penelitian Limbongan dan Soplanit (2007) Kabupaten Jayawijaya yang dipupuk dengan pupuk kandang 5 ton/ha telah menghasilkan ubi jalar sebesar 25,7 ton/ha. Produksi ubi jalar pada beberapa jenis ubi jalar lokal dengan berbagai level pemupukan serasah kompos kambing di lahan terbuka bekas penambangan batu kapur tersaji pada Tabel 3.

Hasil analisis variansi menunjukkan bahwa jenis ubi jalar lokal dan level serasah kompos kambing berpengaruh sangat nyata $(\mathrm{P}<0,01)$ terhadap produksi total ubi jalar namun tidak terjadi interaksi $(\mathrm{P}>0,05)$.

Tabel 3. Produksi ubi jalar (ton/ha) pada beberapa jenis ubi jalar lokal dengan berbagai level pemupukan serasah kompos kambing di lahan terbuka bekas penambangan batu kapur

\begin{tabular}{lrrrr}
\hline & \multicolumn{4}{c}{ Level Pemupukan Serasah Kompos Kambing } \\
\cline { 2 - 5 } Jenis Ubi & $0,5 \mathrm{~kg} / \mathrm{m}^{2}(\mathrm{k} 1)$ & $1 \mathrm{~kg} / \mathrm{m}^{2}(\mathrm{k} 2)$ & $1,5 \mathrm{~kg} / \mathrm{m}^{2}(\mathrm{k} 3)$ & $2 \mathrm{~kg} / \mathrm{m}^{2}(\mathrm{k} 4)$ \\
\hline Ubi Ungu (U) & $9,3^{\text {ac }}$ & $10,8^{\text {ad }}$ & $1,6^{\text {ad }}$ & $10,5^{\text {ad }}$ \\
Ubi Putih (P) & $15,7^{\text {ac }}$ & $18,1^{\text {ad }}$ & $21,5^{\text {ad }}$ & $20,5^{\text {d }}$ \\
Ubi Kuning (K) & $15,1^{\text {bc }}$ & $19,7^{\text {bd }}$ & $21,8^{\text {bd }}$ & $21,1^{\text {bd }}$ \\
\hline
\end{tabular}


Tabel 4. Produksi ubi jalar per tanaman (gram) pada beberapa jenis ubi jalar lokal dengan berbagai level pemupukan serasah kompos kambing di lahan terbuka bekas penambangan batu kapur

\begin{tabular}{lrrrr}
\hline & \multicolumn{4}{c}{ Level Pemupukan Serasah Kompos Kambing } \\
\cline { 2 - 5 } Jenis Ubi & $0,5 \mathrm{~kg} / \mathrm{m}^{2}(\mathrm{k} 1)$ & $1 \mathrm{~kg} / \mathrm{m}^{2}(\mathrm{k} 2)$ & $1,5 \mathrm{~kg} / \mathrm{m}^{2}(\mathrm{k} 3)$ & $2 \mathrm{~kg} / \mathrm{m}^{2}(\mathrm{k} 4)$ \\
\hline Ubi Ungu $(\mathrm{U})$ & $116,7^{\text {ad }}$ & $153,3^{\text {ae }}$ & $191,7^{\text {af }}$ & $136,7^{\text {ae }}$ \\
Ubi Putih (P) & $126,7^{\text {bd }}$ & $168,3^{\text {be }}$ & $276,7^{\text {bf }}$ & $205,0^{\text {be }}$ \\
Ubi Kuning (K) & $135,0^{\text {cd }}$ & $231,7^{\text {ce }}$ & $236,7^{\text {cf }}$ & $220,0^{\text {ce }}$ \\
\hline
\end{tabular}

Hasil uji lanjut memperlihatkan bahwa ubi jalar kuning mempunyai produksi yang lebih tinggi dibandingkan ubi jalar putih dan ungu, sedangkan level pemupukan serasah kompos kambing $1-2 \mathrm{~kg} / \mathrm{m}^{2}$ menghasilkan produksi ubi jalar yang sama tinggi dibandingkan level $0,5 \mathrm{~kg} / \mathrm{m}^{2}$.

\section{Produksi Ubi Jalar per Tanaman (gram)}

Produksi ubi jalar per tanaman berkisar 116 - 276 gram, untuk ubi jalar ungu tertinggi 191 gram, ubi jalar putih 276 gram sedangkan ubi jalar kuning sebesar 236 gram dengan level pemupukan serasah kompos kambing sebanyak $1,5 \mathrm{~kg} / \mathrm{m}^{2}$ atau 15 ton/ha seperti pada Tabel 4. Hasil tersebut hampir sama dengan penelitian Susanto et al. (2014) di Kabupaten Malang yang menghasilkan ubi jalar per tanaman hanya 248 gram padahal dipupuk kompos sapi sebanyak 20 ton/ha. Hasil yang berbeda diperlihatkan dari hasil penelitian Setiawan dan Suryantini (2015) di Kabupaten Kubu Raya Kalimantan Barat dengan menggunakan kompos jerami padi sebanyak 20 ton/ha menghasilkan produksi ubi jalar per tanaman dapat mencapai $750-1.050$ gram. Penelitian Djufri et a.l (2011) di wilayah Kabupatem Kerron Papua bahkan dapat menghasilkan produksi ubi jalar per tanaman sampai 3570 gram.

Hasil analisis variansi menunjukkan bahwa jenis ubi jalar berpengaruh nyata $(\mathrm{P}<0,05)$ terhadap produksi ubi jalar per tanaman, sedangkan level serasah kompos kambing berpengaruh sangat nyata $(\mathrm{P}<0,01)$ terhadap produksi ubi jalar per tanaman. Meskipun demikian tidak terjadi interaksi $(\mathrm{P}>0,05)$ antara jenis ubi jalar lokal dengan level serasah kompos kambing terhadap produksi ubi jalar per tanaman.

Hasil uji lanjut memperlihatkan bahwa ubi jalar kuning mempunyai produksi ubi jalar per tanaman lebih tinggi dibandingkan ubi jalar warna ungu dan putih. Adapun untuk level pemupukan serasah kompos kambing produksi tertinggi ubi jalar per tanaman dipupuk dengan level $1,5 \mathrm{~kg} / \mathrm{m}^{2}$ disusul $2 \mathrm{~kg} / \mathrm{m}^{2}$ dan $1 \mathrm{~kg} / \mathrm{m}^{2}$ sedangkan terendah pada level pemupukan 0,5 $\mathrm{kg} / \mathrm{m}^{2}$.

\section{Berat Ubi Jalar (gram/buah)}

Berat ubi jalar lokal yang dipupuk dengan serasah kompos kambing di lahan terbuka bekas penambangan batu kapur berkisar 83 203 gram seperti tersaji pada Tabel 5. Hasil tersebut tidak jauh berbeda dengan hasil 
penelitian Sasvita et al. (2013) di Binjai Sumatera Utara yang hanya menghasilkan bobot 182 gram. Hasil yang berbeda diperoleh pada penelitian Ginting et al. (2017) di wilayah Deli Serdang Sumatera Utara dengan pemupukan bokashi jerami padi sebanyak 5 ton/ha menghasilkan berat ubi sekitar 402 gram, sedangkan penelitian Pradana et al. (2016) di Kecamatan Medan dapat menghasilkan berat ubi sampai 450 gram. Perbedaan tersebut lebih disebabkan perbedaan kondisi tanah dan jenis ubi jalar yang digunakan. Ditinjau dari berat ubi jalar, penanaman ubi jalar dilahan terbuka bekas penambangan batu kapur dengan pemupukan serasah kompos kambing belum memberikan hasil yang memuaskan. Hasil analisis variansi menunjukkan bahwa jenis ubi jalar dan level pemupukan serasah kompos kambing samasama berpengaruh nyata $(\mathrm{P}<0,05)$ terhadap berat ubi jalar namun tidak terjadi interaksi $(\mathrm{P}>0,05)$ antar keduanya. Hasil uji lanjut menunjukkan bahwa ubi jalar lokal warna kuning mempunyai berat ubi yang paling tinggi dibandingkan dengan ubi warna ungu dan putih. Level pemupukan serasah kompos kambing $1,5 \mathrm{~kg} / \mathrm{m}^{2}$ atau 15 ton/ha mempunyai berat ubi yang paling tinggi.

Tabel 5. Berat ubi jalar (gram) pada beberapa jenis ubi jalar lokal dengan berbagai level pemupukan serasah kompos kambing di lahan terbuka bekas penambangan batu kapur

\begin{tabular}{lrrrr}
\hline & \multicolumn{4}{c}{ Level Pemupukan Serasah Kompos Kambing } \\
\cline { 2 - 5 } Jenis Ubi & $0,5 \mathrm{~kg} / \mathrm{m}^{2}(\mathrm{k} 1)$ & $1 \mathrm{~kg} / \mathrm{m}^{2}(\mathrm{k} 2)$ & $1,5 \mathrm{~kg} / \mathrm{m}^{2}(\mathrm{k} 3)$ & $2 \mathrm{~kg} / \mathrm{m}^{2}(\mathrm{k} 4)$ \\
\hline Ubi Ungu (U) & $83,3^{\text {ac }}$ & $100,0^{\text {ac }}$ & $155,0^{\text {ad }}$ & $105,0^{\text {ac }}$ \\
Ubi Putih (P) & $100,0^{\text {ac }}$ & $90,0^{\text {ac }}$ & $153,3^{\text {ad }}$ & $128,3^{\text {ac }}$ \\
Ubi Kuning (K) & $118,3^{\text {bc }}$ & $140,0^{\text {bc }}$ & $203,3^{\text {bd }}$ & $190,0^{\mathbf{b c}}$ \\
\hline
\end{tabular}

Tabel 6. Panjang ubi jalar (cm) pada beberapa jenis ubi jalar lokal dengan berbagai level pemupukan serasah kompos kambing di lahan terbuka bekas penambangan batu kapur

Level Pemupukan Serasah Kompos Kambing

\begin{tabular}{lrrrr}
\cline { 2 - 5 } Jenis Ubi & $0,5 \mathrm{~kg} / \mathrm{m}^{2}(\mathrm{k} 1)$ & $1 \mathrm{~kg} / \mathrm{m}^{2}(\mathrm{k} 2)$ & $1,5 \mathrm{~kg} / \mathrm{m}^{2}(\mathrm{k} 3)$ & $2 \mathrm{~kg} / \mathrm{m}^{2}(\mathrm{k} 4)$ \\
\hline Ubi Ungu (U) & $12,0^{\mathbf{a b}}$ & $13,8^{\mathbf{a c}}$ & $15,4^{\mathbf{a c}}$ & $14,3^{\mathbf{a c}}$ \\
Ubi Putih (P) & $8,7^{\mathbf{a b}}$ & $11,5^{\mathbf{a c}}$ & $16,3^{\mathbf{a c}}$ & $14,0^{\mathbf{a c}}$ \\
Ubi Kuning (K) & $12,0^{\mathbf{a b}}$ & $14,5^{\mathbf{a c}}$ & $13,9^{\mathbf{a c}}$ & $14,1^{\mathbf{a c}}$ \\
\hline
\end{tabular}

Tabel 7. Diameter ubi jalar $(\mathrm{cm})$ pada beberapa jenis ubi jalar lokal dengan berbagai tingkat pemupukan serasah kompos kambing di lahan terbuka bekas penambangan batu kapur

Level Pemupukan Serasah Kompos Kambing

\begin{tabular}{lrrrr} 
Jenis Ubi & $0,5 \mathrm{~kg} / \mathrm{m}^{2}(\mathrm{k} 1)$ & $1 \mathrm{~kg} / \mathrm{m}^{2}(\mathrm{k} 2)$ & $1,5 \mathrm{~kg} / \mathrm{m}^{2}(\mathrm{k} 3)$ & $2 \mathrm{~kg} / \mathrm{m}^{2}(\mathrm{k} 4)$ \\
\hline Ubi Ungu (U) & $3,1^{\text {ac }}$ & $3,6^{\text {ac }}$ & $4,8^{\text {ad }}$ & $3,9^{\text {ad }}$ \\
Ubi Putih (P) & $3,5^{\text {bc }}$ & $3,9^{\text {bc }}$ & $4,8^{\text {bd }}$ & $4,9^{\text {bd }}$
\end{tabular}




$\begin{array}{lllll}\text { Ubi Kuning (K) } & 3,7^{\mathbf{b c}} & 4,2^{\text {bc }} & 5,4^{\text {bd }} & 4,7^{\text {bd }}\end{array}$

\section{Panjang Ubi Jalar (cm)}

Panjang ubi dapat mempengaruhi produktivitas ubi jalar, panjang ubi hasil penelitian di lahan terbuka bekas penambangan batu kapur sekitar $8,7-16,3 \mathrm{~cm}$ seperti pada Tabel 6. Panjang ubi hasil penelitian yang maksimal hanya mencapai $16,3 \mathrm{~cm}$ tidak berbeda jauh dengan panjang ubi di wilayah Sumetera Utara yang dilakukan Sasvita et. al. (2013) yaitu 13,3 cm dan Pradana et al. (2016) dengan panjang 7,5 $22,5 \mathrm{~cm}$.

Hasil analisis variansi memperlihatkan bahwa jenis ubi jalar lokal berpengaruh tidak nyata $(\mathrm{P}>0,05)$ terhadap panjang ubi, sedangkan level pemupukan serasah kompos kambing berpengaruh sangat nyata $(\mathrm{P}<0,01)$ terhadap panjang ubi. Hasil uji lanjut menunjukkan bahwa level pemupukan $1-2$ $\mathrm{kg} / \mathrm{m}^{2}$ mempunyai panjang ubi yang sama, adapun level pemupukan 0,5 $\mathrm{kg} / \mathrm{m}^{2}$ mempunyai panjang ubi yang berbeda dan pendek.

\section{Diameter Ubi jalar (cm)}

Diameter ubi jalar akan mempengaruhi berat ubi sehingga akan mempengaruhi produksi ubi jalar secara keseluruhan. Diameter ubi jalar pada penelitian ini diperoleh kisaran sebesar 3,1-5,4 cm, untuk ubi ungu 3,1 - 4,8 cm, ubi putih 3,5 - 4,9 dan ubi kuning 3,7 - 5,4 cm seperti pada Tabel 7 .
Hasil ini cukup berbeda dengan hasil penelitian Serly et al. (2013) di Makasar Sulawesi Selatan yang menghasilkan diameter ubi sebesar 5,26 - 5,81 cm dengan menggunakan pupuk daun Growmore 6-30-30.

Hasil analisis variansi menunjukkan bahwa jenis ubi kayu dan level pemupukan berpengaruh sangat nyata $(\mathrm{P}<0,01)$ terhadap diameter ubi jalar namun tidak terjadi interaksi $(\mathrm{P}>0,05)$ antar kedua faktor. Hasil uji lanjut memperlihatkan bahwa ubi jalar ungu berbeda dengan ubi jalar putih dan kuning karena mempunyai diameter paling kecil. Adapun level pemupukan serasah kompos kambing 0,5 $\mathrm{kg} / \mathrm{m} 2$ dan $1 \mathrm{~kg} / \mathrm{m} 2$ mempunyai diameter ubi yang sama kecilnya, sedangkan level pemupukan $1,5 \mathrm{~kg} / \mathrm{m} 2$ dan $2 \mathrm{~kg} / \mathrm{m} 2$ mempunyai diameter ubi yang sama-sama besar. Berdasarkan hasil dari diameter ubi menunjukkan bahwa ubi putih dan ubi kuning dengan level pemupukan $1,5-2 \mathrm{~kg} / \mathrm{m} 2$ mempunyai diameter ubi yang besar.

\section{KESIMPULAN}

Jenis ubi jalar mempengaruhi produktivitas ubi jalar di lahan terbuka bekas penambangan batu kapur, adapun produktivitas yang paling tinggi adalah jenis ubi jalar kuning. Level pemupukan serasah kompos kambing mempengaruhi produktivtas ubi jalar di lahan terbuka bekas penambangan batu kapur, adapun level pemupukan serasah kompos 
kambing minimal sebanyak $1 \mathrm{~kg} / \mathrm{m}^{2}$ atau 10 ton/ha. Tidak terjadi interaksi antara jenis ubi jalar dengan level pemupukan serasah kompos kambing terhadap produktivitas ubi jalar di lahan terbuka bekas penambangan batu kapur.

\section{UCAPAN TERIMA KASIH}

Ucapan terima kasih ditujukan kepada

Direktorat Riset dan Pengabdian Masyarakat Ditjen Penguatan Riset dan Pengembangan Kementerian Riset, Teknologi dan Pendidikan Tinggi dengan Surat Nomor : 006/L6/AK/AK/SP2H.1/PENELITIAN/2019.

\section{DAFTAR PUSTAKA}

Azizah, A. B.Zaman, Purnomo. 2017. Pengaruh penambahan campuran pupuk kotoran sapi dan kambing terhadap kualitas TPST Undip Semarang. Jurnal Teknik Lingkungan 6 (3) : 1 - 100.

Balitbangtan Kementerian Pertanian. 2015. Petunjuk Teknis Pelaksanaan Penenelitian Kesuburan Tanah. Balai Penelitian

Tanah.http://balittanah.litbang.pertanian. go.id/ind/index.php/en/berita-terbarutopmenu-58. Diakses 19 September 2019.

Djufry, F., M.S. Lestari, Arifuddin dan A.Soplanit. 2011. Pertumbuhan dan produksi ubi jalar di dataran rendah pada berbagai varietas dan sumber stek. J. Agrivigor 10 (3) : 228-234.

Ginting, W.A.P., J. Ginting, N. Rahmawati. 2017. Respon pertumbuhan dan produksi varietas ubi jalar ungu (Ipomoea batatas) terhadap pemberian bernagai dosis bokashi jerami padi.

Jurnal Agroekoteknologi FP USU 5 (1) : $233-239$.

Limbongan, J. dan A. Soplanit. 2007.

Ketersediaan teknologi dan potensi pengembangan ubi jalar. Jurnal Litbang Pertanian 26 (4) : 131 - 138.

Pradana, R.E., N. Rahmawati, Mariati. 2016. Pengaruh pemberian pupuk organik terhadap pertumbuhan dan produksi ubi jalar ungu (Ipomoea batatas L.). Jurnal Agroekoteknologi 4 (4) : 2212 - 2217.

Sarwanto, D dan C.H. Prayitno. 2015. The diversity and productivity of indigenous forage in former limestone mining quarry in karst mountain of Southern Gombong, Central Java Indonesia. Journal Animal Production. Vol. 17 No.2 (2015) May : 69 - 75.

Sarwanto, D., S.E. Tuswati, dan P. Widodo. 2015. Keragaman dan produktivitas hijauan pakan indigenous pada berbagai tingkat kerapatan vegetasi di pegunungan kapur Gombong Selatan. Biosfera. Vol. 32 (3) September 2015 : $147-153$.

Sarwanto, D. dan S.E.. Tuswati. 2016. Komposisi hijauan pakan kambing di lereng pegunungan kapur Gombong Selatan - Jawa Tengah. Prosiding Seminar Nasional Kebangkitan Peternakan II. 12 Mei 2016, Program Studi Magiter Ilmu Ternak Fakultas Peternakan dan Pertanian Universitas Diponegoro, Semarang Indonesia : 350 354.

Sarwanto, D. dan S.E. Tuswati. 2017. Pertumbuhan rumput Gajah kerdil (Pennisetum purpureum 'Mott') di lahan terbuka bekas penambangan batu kapur kawasan karst Gombong Jawa Tengah. Biosfera. Vol 34, No (3) September (2017) : 131- 137.

Sarwanto, D. dan S.E. Tuswati. 2018. Introduction of dwarf Elephant grass (Pennisetum purpureum cv. Mott) and annual legumes in the disused limestone mining in karst Gombong Area, Central Java, Indonesia. Bulletin of Animal Science. Vol .42 No (1) (2018) February : 57-61.

Sasvita, W., C. Hanum, E. Purba. 2013. Pertumbuhan dan hasil tiga klon ubi jalar pada jarak tanam yang berbeda. Jurnal Agroekoteknologi. 2 (1) : $462-473$.

Serly, E.L. Sengin, M. Riadi. 2013. Respon pertumbuhan dan produksi ubi jalar (Ipomoea batatas L.) yang diaplikasi Paclobutrazol dan Growmore 6-30-30. Jurusan Budidaya Pertanian, Fakultas 
Pertanian, Universitas Hasanuddin

Makassar.

Setiawan dan Suryantini. 2015. Peningkatan produktivitas beberapa varietas lokal ubi jalar (Ipomoea batatas) dengan pupuk organik alam dan pupuk buatan. Jurnal Agrosains Vol. 12 (2) : 1 - 7 .

Susanto, E., N. Herlina, N.E. Suminarti. 2014. Respon pertumbuhan dan hasil tanaman ubi jalar pada berbagai macam dan waktu aplikasi bahan organik. Jurnal Produksi Tanaman 2 (5) : 412 - 418.

Steel, R.G.D dan J.H. Torrie. 1993. Prinsip dan Prosedur Statistika : Suatu pendekatan biometrik. Penerbit PT Gramedia Pustaka Utama, Jakarta. 